\title{
GENETIC STUDY FOR A PART OF LACTATION PERIOD IN FRIESIAN COW
}

\author{
SOFFIAN A. A. DABDOUB \\ Professor, Department of Veterinary Public Health, College of Veterinary Medicine, University of Mosul, Mosul, Iraq \\ Email: soffiandabdoub1951@yahoo.com
}

\section{ABSTRACT}

Received at: $26 / 12 / 2013$

This work was conducted to investigate a genetic relationship between part lactation period and total milk yield, in order to take advantage the information provided by a part record of lactation period (months) for evaluating of production efficiency which bulls can be evaluated for sire index. This study was included a monthly milk

Accepted: 25/2/2014 yield of 424 lactation records during 1978-2001 of pure breed Friesian in Mosul city (Iraq). The records were adjusted for fixed effects of calving season and monthly milk production records. The maximum average milk production was in the second month $(395.6 \mathrm{~kg})$. The highest heritability $\left(\mathrm{h}^{2}\right)$ estimated was $(0.41)$ in the production of the third month, therefore, the production of the third month may be utilized for selecting animals for rapid improvement. While, the highest heritability estimated for cumulative monthly production was $(0.32)$ for the first four month of lactation. Coefficients of genetic and phenotypic correlation between monthly milk production and total lactation production showed increasing trend with increase a cumulative months in milk production. The results of heritabilities and genetic correlation reveal that the part of milk production record was based on the third month of milk production was efficient as the total lactation production.

Keyword: milk yield, monthly and cumulative milk production, heritability, genetic and phenotypic correlations.

\section{INTRODUCTION}

The milk production of dairy animals is one of the major factors besides age at first calving and breeding efficiency, which effect the economics of dairy enterprise (Groen et al., 1996; Pedersen 1997 and Purwantara et al., 2001).

Holstein- Friesian considered the most prevalent dairy breeds over the world due to their characteristic and production ability as well as their adaptation to the different climate. Breeders are interested in this breed and they try to increase their production by genetic improvement and best management (Schmidt et al., 1988; Maule, 1990; Caraviello 2004 and Dabdoub 2005).

The genetic makeup of the cows as well as the nongenetic factors have great effects on dairy merits (Jones et al., 1994). Therefore the information on the inheritance of a part of lactation period and their relationship with total lactation production are rather scanty (Bastos, 1989; Fuerst and Solkner, 1994; Smith and Becker, 1999; White et al., 1999; Purwantara et al., 2001 and Van Arendonk and Liinamo, 2003).

The aim of this work was conducted to investigate the genetic relationship between a part of lactation period and total milk yield and suggest the part record of milk production on which bulls can be evaluated for sire index. Therefore, estimate the heritabilities of monthly, cumulative monthly and total lactation production, as well as to study genetic and phenotypic relationship of cumulative monthly milk yield with total milk production.

\section{MATERIALS and METHODS}

The monthly milk yield of 424 normal lactations records completed during 1978-2001 by pure breed Friesian cows, from Al-Rashidia farm in Mosul city (Iraq) were included in this study. The records were adjusted for significant effect of calving season and lactation months as described by Cunningham (1980) and Becker (1985). The inheritance was studied in terms of heritability based on monthly and cumulative monthly milk production records.

The following equation describes the data for genetic and environmental study of milk production:

$$
\mathrm{Y}_{\mathrm{ij}} \mathrm{klm}=\mu+\mathrm{Li}+\mathrm{C}_{\mathrm{j}}+\mathrm{S}_{\mathrm{k}}+\mathrm{D}_{\mathrm{kl}}+\zeta_{\mathrm{jij}} \mathrm{klm}
$$

Where, $\mathrm{Y}_{\mathrm{ij}} \mathrm{klm}$ : is total lactation production, cumulative monthly milk production, or monthly milk production of the $\mathrm{m}^{\text {th }}$ record of the $\mathrm{i}^{\text {th }}$ cow and $\mathrm{k}^{\text {th }}$ sire in $\mathrm{j}^{\text {th }}$ season of calving and $\mathrm{i}^{\text {th }}$ lactation.

$$
\begin{aligned}
& \mu \text { : overall mean } \\
& \mathrm{Li} \text { : fixed effect of } \mathrm{r}^{\text {th }} \text { lactation. }
\end{aligned}
$$


$\mathrm{C}_{\mathrm{j}}$ : fixed effect of $\mathrm{j}^{\text {th }}$ calving season.

$\mathrm{S}_{\mathrm{k}}$ : random effect associated with $\mathrm{k}^{\text {th }}$ sire.

$\mathrm{D}_{\mathrm{kl}}$ : random effect associated with $1^{\text {th }}$ dam within $\mathrm{k}^{\text {th }}$ sire.

$\zeta_{\mathrm{ij}} \mathrm{klm}$ : random effect.

Four classes of lactation were parity 1, 2, 3 and 4, parity 4 included $4^{\text {th }}$ and later lactation. Calving season was divided into four classes as follows: $1^{\text {st }}$ class for winter season (December, January, February), $2^{\text {nd }}$ class for spring season (March, April, May), $3^{\text {rd }}$ class for summer season (June, July, August), and $4^{\text {th }}$ class for fall season (September, October, November).

Random effects were assumed to have zero mean and variance $\sigma_{\mathrm{s}}{ }^{2}, \sigma_{\mathrm{D}}{ }^{2}$ and $\sigma_{\mathrm{e}}{ }^{2}$, are sire, cow and error components of variance. From estimating these variance components, heritability estimates were obtained for sire variance component which represent half-sib covariance and the formula is:

$$
\hat{\mathrm{h}}_{\mathrm{s}}^{2}=\frac{4 \sigma s^{2}}{4 \sigma s^{2}+4 \sigma D^{2}+4 \sigma e^{2}}
$$

Where $\sigma_{\mathrm{s}}{ }^{2},{\sigma_{\mathrm{D}}}^{2}$ and $\sigma_{\mathrm{e}}{ }^{2}$ are estimated for the sire, cow and error component of variance (Cunningham 1980, and Becker, 1985). The variance for heritabilities and hence SE $\left(\mathrm{h}^{2}\right)$, as well as the genetic and phonotypic correlation and their standard error were estimated as described by Cunningham (1980) and Becker (1985), these estimates were based on the record having complete lactation length of at least 180 days.

Averages cumulative monthly yields were estimated from records having complete lactation length of 270 days. Whereas, genetic and phenotypic correlation of total lactation production with cumulative monthly milk production were estimated for records having complete lactation length more than ten months.

\section{RESULTS and DISCUSSION}

The averages monthly and cumulative monthly yield with their standard errors and coefficients of variation along with their estimates of heritability $\left(h^{2}\right)$ and standard errors (SE) are presented in Table (1).

Table 1: Average monthly milk production along with their estimates of heritability $\left(\mathrm{h}^{2}\right)$ and standard errors (SE).

\begin{tabular}{ccccccc}
\hline Month of lactation & $\begin{array}{c}\text { Number of } \\
\text { observations }\end{array}$ & $\begin{array}{c}\overline{\mathbf{X}} \mathbf{k g} \\
\text { average }\end{array}$ & $\mathbf{S E}$ & $\mathbf{C V} \%$ & $\mathbf{h}^{2}$ & SE \\
\hline First & 424 & 382.5 & 2.36 & 12.7 & 0.24 & 0.12 \\
\hline Second & 424 & 395.6 & 2.43 & 12.6 & 0.27 & 0.13 \\
\hline Third & 424 & 349.0 & 2.38 & 14.0 & 0.41 & 0.16 \\
\hline Fourth & 424 & 324.9 & 2.24 & 14.2 & 0.39 & 0.14 \\
\hline Fifth & 424 & 305.6 & 2.39 & 16.1 & 0.30 & 0.12 \\
\hline Sixth & 424 & 296.2 & 2.33 & 16.1 & 0.22 & 0.11 \\
\hline Seventh & 396 & 278.3 & 2.29 & 16.4 & 0.16 & 0.14 \\
\hline Eighth & 338 & 259.5 & 2.32 & 16.6 & 0.17 & 0.15 \\
\hline Ninth & 289 & 254.7 & 2.50 & 16.7 & 0.19 & 0.11 \\
\hline Tenth & 247 & 245.1 & 2.60 & 16.8 & 0.08 & 0.20 \\
\hline Eleventh & 216 & 200.9 & 2.29 & 17.0 & 0.07 & 0.16 \\
\hline $\begin{array}{c}\text { overall total lactation } \\
\text { production }\end{array}$ & 424 & 3318.9 & 34.9 & 21.6 & 0.26 & 0.17 \\
\hline
\end{tabular}

The average monthly milk production increased only up to the second month $(395.6 \mathrm{~kg} \pm 2.43)$, where in peak was attained. In subsequent months it decline gradually as the lactation advanced which is clear after the third month. Maximum variability (coefficients of variation, C.V.) was observed in the last month, and minimum in the first two months of lactation period.

The estimates of heritability along with their standard errors for monthly milk production are shown in Table (1). These estimates were in the range of other estimates (Pedersen, 1997; White et al., 1999; and
Purwantara et al., 2001). They reported that the highest heritability was estimated for the fifth month's production. While, in the present study it was the highest for the third month of lactation period (Table 1). This difference could be due to the variation in lactation length and other traits among herd. The estimates of heritabilities for production of the last two months were not significant different from zero. Similar results were reported by (White et al., 1999; Van Arendonk and Liinamo, 2003).

In general, the heritability estimates of milk production be increased from the first to the third 
month of lactation period and decline then after. Similar trend was reported (White et al., 1999; Purwantara, 2001; Van Arendonk and Liinamo, 2003). Thus, the production of the third month may be utilized for selecting animals for rapid improvement of milk production and for evaluation of breeding value.
The heritability estimates of various cumulative monthly production records (Table 2) showed the highest estimate $(0.32 \pm 0.19)$ for the production in the first four months of lactation period. In which the cumulative monthly milk production was $(14503 \pm$ 9.34).

Table 2: Cumulative monthly milk production along with their estimate of heritability $\left(\mathrm{h}^{2}\right)$ and standard errors (SE).

\begin{tabular}{ccccccc}
\hline $\begin{array}{c}\text { (Month) } \\
\text { cumulative yield }\end{array}$ & $\begin{array}{c}\text { No. of observations } \\
\text { in each month }\end{array}$ & $\begin{array}{c}\overline{\mathbf{X}} \text { average } \\
\mathbf{k g}\end{array}$ & $\mathbf{S E}$ & $\mathbf{C V} \%$ & $\mathbf{h}^{\mathbf{2}}$ & $\mathbf{S E}$ \\
\hline First two & 289 & 776.5 & 5.82 & 12.7 & 0.26 & 0.18 \\
\hline First three & 289 & 1120.6 & 7.38 & 11.3 & 0.31 & 0.18 \\
\hline First four & 289 & 1450.3 & 9.34 & 11.0 & 0.32 & 0.19 \\
\hline First five & 289 & 1756.9 & 10.83 & 10.5 & 0.30 & 0.17 \\
\hline First sex & 289 & 2058.1 & 12.58 & 10.4 & 0.27 & 0.18 \\
\hline First seven & 289 & 2350.4 & 14.23 & 10.3 & 0.25 & 0.16 \\
\hline First eight & 289 & 2620.3 & 15.79 & 10.3 & 0.26 & 0.17 \\
\hline First nine & 289 & 2875.0 & 17.26 & 10.2 & 0.24 & 0.16 \\
\hline First ten & 247 & 3120.1 & 19.80 & 10.0 & 0.25 & 0.17 \\
\hline up to last day & 216 & 3321.0 & 21.48 & 9.6 & 0.23 & 0.18 \\
\hline
\end{tabular}

2003). The coefficients of phenotypic correlation of the cumulative a part of production of varying durations, with the complete lactation production, showed increasing trend with addition of each month of milk production (Table 3 ).
Considerably high coefficients of genetic correlation were between the cumulative monthly milk production and total milk production (Table 3). Similar results were reported by (White et al., 1999; Purwantara, 2001; Van Arendonk and Liinamo,

Table 3: Genetic and phenotypic correlation of total lactation production with cumulative monthly milk production.

\begin{tabular}{ccccc}
\hline $\begin{array}{c}\text { Duration of lactation } \\
\text { production }\end{array}$ & $\begin{array}{c}\text { Genetic } \\
\text { correlation }\end{array}$ & $\begin{array}{c}\text { SE of Gen. } \\
\text { Corr. }\end{array}$ & $\begin{array}{c}\text { Phenotypic } \\
\text { Correlation }\end{array}$ & $\begin{array}{c}\text { SE of Phen. } \\
\text { Corr. }\end{array}$ \\
\hline First month & 0.80 & 0.11 & 0.69 & 0.08 \\
\hline First 2 months & 0.88 & 0.09 & 0.74 & 0.08 \\
\hline First 3 months & 0.90 & 0.08 & 0.78 & 0.07 \\
\hline First 4 months & 0.91 & 0.07 & 0.81 & 0.06 \\
\hline First 5 months & 0.93 & 0.07 & 0.89 & 0.06 \\
\hline First 6 months & 0.97 & 0.03 & 0.92 & 0.05 \\
\hline First 7 months & 0.98 & 0.01 & 0.94 & 0.03 \\
\hline First 8 months & 0.99 & 0.01 & 0.97 & 0.01 \\
\hline First 9 months & 1.00 & - & 0.99 & 0.01 \\
\hline First 10 months & 1.00 & - & 0.99 & 0.01 \\
\hline
\end{tabular}

All the coefficients were high, and compared fairly with other reports (Pedersen, 1997; White et al., 1999; Purwuntara et al., 2001; Van Arendonk and Liinami 2003; Caraviello, 2004).

Considering the estimates of heritability and correlations together, it can be concluded that for the purpose of sire index, estimating the breeding value of cows and bulls, and selection for maximum genetic gains in milk yield, a part of milk production record was based on the third month's production was efficient as the total lactation production. 


\section{REFERENCES}

Bastos, J.F.P. (1989): Genetic and non-genetic factors affecting milk yield and lactation length in a herd of Guzera cows (in spanish). Anim. Breed. Abstr. 58:82.

Becker, W.A. (1985): Mannual of quantitive genetics. $4^{\text {th }}$ ed. Student Book Corporation, Washington, USA.

Caraviello, D.Z. (2004): Crossbreeding dairy cattle. The Babcock Institute, Board of Regents of the University of Wisconsin-Madison. Reproduction and Genetics: No.610.

Cunningham, E.P. (1980): Animal breeding theory. $2^{\text {nd }} \quad$ ed. Landbruksbokhandelen, Universitetsforlaget, Vollebekk, Oslo, Norway.

Dabdoub, S.A. (2005): Effect of dry period and days open on Friesian milk production in Iraq. AlAnbar J. of Agric. Sci., 3(1): 11-20.

Fuerst, C. and Solkner, J. (1994): Additive and nonadditive genetic variances for milk yield, fertility and life time performance traits of dairy cattle. J. dairy Sci. 77: 1117-1125.

Groen, A.F.; Steine, T.; Colleau, J.J.; Pedersen, J.; Pribyl, J. and Reinsch, N. (1996): Economic values in dairy cattle breeding, with special reference to functional traits. Report of an EAAP- working group. 47 Annual Meeting of EAAP, Lillehammer, Norway. 25-29 August.

Jones, W.P.; Hasen, L.B. and Chestar-Jones, H. (1994): Response of health care to selection for milk yield of dairy cattle. J. dairy Sci. 77: 3137-3152.

Maule, K. (1990): Evaluation of results of animal husbandry in 1980. Nas. Chove. (6)90: 241-244.

Pedersen, J. (1997): The importance of functional traits. The European Holstein Friesian confederation, The $23^{\text {rd }}$ European conference, Danish Agricultural Advisory center, Denmark. 21-24 September.

Purwantara, B.; Achjadi, R.K.; Tambing, S.N. and Wicaksono, C.N. (2001): The effect of season and milk production on reproductive performance in dairy cows. Proceeding of the $10^{\text {th }}$ conference of the Association on Institution for Tropical Veterinary Medicine. Copenhagen, Denmark.20-24August.

Schmidt, G.H.; Van Vleck, L.D. and Hutjents, M.F. (1988): Principle of dairy science. Prentice Hall Englewood Cliffs, New Jersey, USA.

Smith, J.F. and Becker, K.A. (1999): The reproductive status of your dairy herd. Cooperative Extension Service, College of Agriculture and Home Economic, Univ. of New Mexico.

Van Arendonk, J.A.M. and Liinamo, A.E. (2003): Dairy cattle production in Europs. Theriogenology. 59(2): 563-569.

White, I.M.S.; Thompson, R. and Brotherstone, S. (1999): Genetic and environmental smoothing of lactation curves with cubic splines. J. Dairy Sci. 82:632-638.

\title{
دراسة وراثية لجزء من فترة الحليب في أبقار الفريزيان \\ سفيان عبد العزيز دبدوب \\ Email: soffiandabdoub1951@yahoo.com
}

\begin{abstract}
صمم البحث لدراسة العلاقة الور اثية بين الإنتاج لجزء من فترة الحليب و إنتاج الحليب الكلي، لأجل الاستفادة من المعلومات التئي

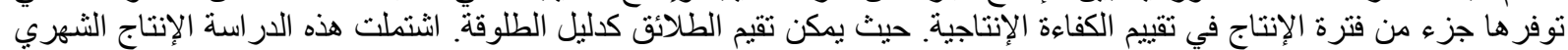

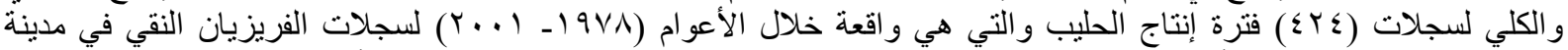

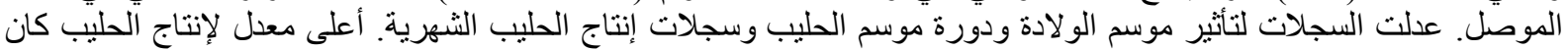

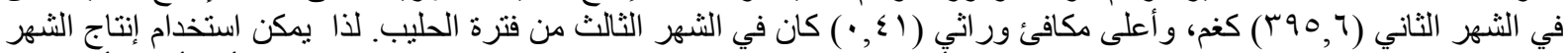

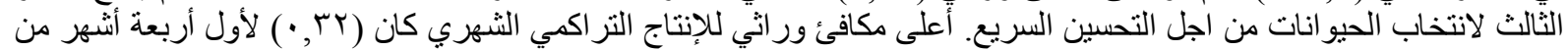

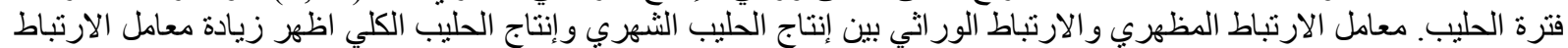

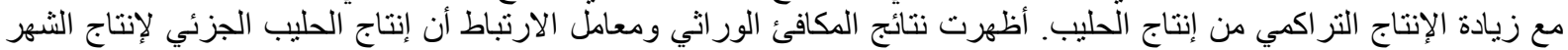
الثالث له نفس كفاءة الإنتاج الكلي لفترة إنتاج الحلبي.

الكلمات الدالة: إنتاج الحليب الكلي و الثهري التر اكمي، الدكافئ الور اثي، الارتباط الور اثي و المظهري.
\end{abstract}

